\title{
ASPEK EKONOMI PADA KEHIDUPAN PEREMPUAN LANJUT USIA: Studi Etnografi di Desa Demuk, Kecamatan Pucanglaban, Kabupaten Tulungagung
}

\author{
Richa Meliza ${ }^{1 *}$, Budiawati Supangkat Iskandar ${ }^{2}$, Rini S. Soemarwoto ${ }^{3}$ \\ ${ }_{1}^{1}$ Graduate Student of Department of Anthropology, Universitas Padjajaran, Bandung, Indonesia \\ 2 Department of Anthropology, Universitas Padjajaran, Bandung, Indonesia \\ ${ }^{3}$ Department of Anthropology, Universitas Padjajaran, Bandung, Indonesia
}

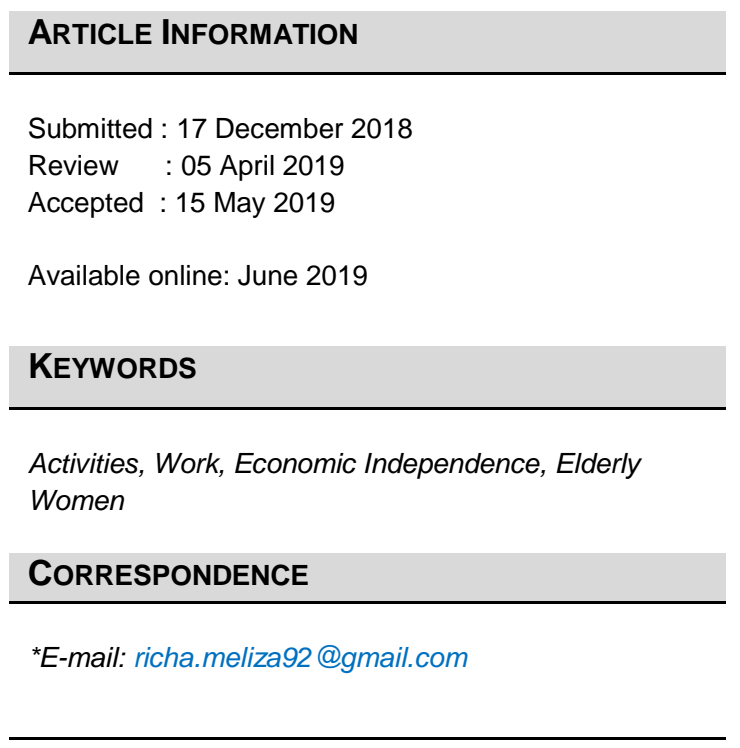

\section{A. PENDAhUluan}

ndonesia akan mengalami bonus demografi di tahun 2020-2036, bonus demografi sendiri adalah besarnya penduduk usia produktif antara 15 tahun hingga 64 tahun dalam suatu negara. Melihat kepada persoalan dan perubahan-perubahan yang berhubungan dengan permasalahan penduduk seperti fertilitas, mortalitas dan migrasi, sehingga akan menghasilkan suatu keadaan perubahan komposisi penduduk dari umur dan jenis kelamin serta mengubah struktur penduduk secara keseluruhan. Komposisi penduduk Indonesia akan didominasi oleh kelompok usia produktif yang akan menjadi mesin pendorong pertumbuhan ekonomi ${ }^{1}$. Dalam tren demografi saat ini, fenomena bonus demografi menurut Badan Pusat Statistik (BPS) akan diprediksikan bahwa bonus demografi di Indonesia yang dimulai pada tahun 2020 sampai tahun 2036 mendatang bisa dikatakan, benar-benar suatu

\footnotetext{
${ }^{1}$ https://regional.kompas.com/read/2018/10/08/05440801/bonusdemografi-indonesia-berakhir-di-2036-jumlah-lansia-bakal-naik (Ari Maulana Karang. Akses 28/2/2019. Pkl. 20.51)
}

\begin{abstract}
A B S T R A C T
Indonesia is predicted to enter the era of bonus demography which is an interesting issue now. This is related to the increasing productive and non-productive population. This phenomenon can benefit the population, both productive and non-productive residents who get less attention, especially economic dependence on nonproductive groups such as the elderly. Elderly are often said to be a burden on society, especially for women who are often associated with domestic work. This study raises the economic independence of elderly women. The method used in this study is a qualitative approach on elderly women in Demuk village, Pucanglaban sub-district, Tulungagung district. Data collection uses participatory observation techniques and in-depth interviews. The results of the study show that elderly women can meet the economic needs of their own family or household. They work in the domestic and public domains such as farmers, laborers, traders, and breeders. Thus elderly women are not burdens, but they become economic support for the family or household
\end{abstract}

bonus yang dapat meningkatkan suatu perekonomian dan meningkatkan kesejahteraan masyarakat Indonesia atau malah, jika tidak dimanfaatkan dengan baik bonus ini akan menjadi suatu bencana bagi Indonesia.

Indonesia bukan salah satu negara yang berhasil memasuki bonus demografi, melainkan negara-negara yang sebelumnya sudah berhasil yaitu negara Tiongkok, Korea Selatan, Thailand, Jepang yang sudah terlebih dahulu memanfaatkan kondisi bonus demografi dengan sangat baik dalam segi perekonomian dan industri kreatifitas. Sementara itu menurut pengamat negara, yang dinilai gagal dalam mencapaikan keberhasilan bonus demografi, yaitu negara Brazil dan Afrika Selatan. Kedua negara ini gagal karena kurang berhasil dalam memenuhi syaratsyarat dalam keberhasilan yang maksimal dalam suatu bonus demografi ${ }^{2}$.

Tantangan dalam mengoptimalkan bonus demografi menurut Sulistyastuti (2017) secara teoritis bonus ini memberikan keuntungan yang

\footnotetext{
${ }^{2}$ http://video.metrotvnews.com/primetime-news/GNGLOzlbtantangan-bonus-demografi-bagi-indonesia (Robert Harianto. Akses 28/3/2019. Pkl. 11.59) 
sangat banyak dalam segi ekonomi sebuah negara, dimana tingkat rasio ketergantungan akan menurun dan diikuti dengan penduduk usia produktif. Akan tetapi jika penduduk usia produktif tidak memanfaatkan dengan baik peluang ini, maka akan menjadi suatu bencana bagi sebuah negara dalam segi perekonomian.

Usai bonus demografi ini, tantangan baru akan datang yakni bertambah banyak jumlah penduduk berusia lanjut. Indonesia diperkirakan pada abad ke-21 ini mempunyai karakteristik yang akan meningkat jumlah penduduk lanjut usia atau menua. Menurut Priyoto (2015), menua atau dengan sebutan lansia adalah suatu proses menghilangnya secara perlahan-lahan kemampuan jaringan untuk melakukan fungsinya dalam memenuhi kebutuhan dalam hidup. Proses menua merupakan proses yang terus menerus (berlanjut) secara alamiah. Menjadi tua merupakan proses alamiah, yang berarti seseorang telah melalui tiga tahap kehidupan yaitu anak-anak, dewasa dan tua. Tiga tahap ini berbeda, baik secara biologis maupun psikologis. Proses tahapan ini berpengaruh pada angka kematian dan kelahiran yang secara demografi akan meningkatkan jumlah penduduk di Indonesia, terutama berpengaruh terhadap lanjut usia.

Perubahan dalam demografi yang dialami Indonesia seyogianya dikawal dengan baik. Jika lengah dalam pengawasan demografi tersebut dikhawatirkan akan muncul berbagai masalah salah satunya pada kelompok lansia. Fadilah (2015) mengungkapkan bahwa kelompok sosial lansia adalah lapisan masyarakat yang memiliki nilai budaya dan norma yang baik, dihormati, dikasih, bijaksana dan dipercaya dalam menjaga keutuhan nilai-nilai agama dan menjadi tetua dikalangan masyarakat luas, sehingga mereka memiliki posisi yang istimewa. Tetapi seiring dengan terjadinya perkembangan dan perubahan di zaman sekarang ini, nilai tersebut telah bergeser. Sekarang telah terjadi degradasi ${ }^{3}$ nilainilai norma terhadap lansia, terutama pada masyarakat yang berkaitan dengan keuangan atau ekonomi. Sebagian besar beranggapan lansia hanyalah beban dan bergantung kepada orang lain sehingga tidak adanya eksistensi lansia lagi di kalangan masyarakat. Fakta dari laporan PBB disaat memperingati Hari Penduduk Dunia di tahun 2017 dengan teman "Prospek Populasi Dunia" menunjukkan bahwa jumlah penduduk Indonesia selama 40 tahun kedepan menjadi dua kali lipat tetapi penduduk lansia bertambah sepuluh kali lipat, dikarenakan usia harapan hidup yang semakin meningkat dari tahun ke tahun.

Dalam kehidupan sehari-hari, lanjut usia merupakan proses dalam lingkaran hidup manusia yang hampir pasti dialami setiap orang.

${ }^{3}$ Degradasi adalah kemunduran, kemerosotan dan penurunan. 12 | $P$ a $g$ e
Kenyataan saat ini, setiap kali menyebut kata lanjut usia yang terbesit adalah seseorang yang kurang berdaya, dan memiliki banyak keluhan kesehatan. Padahal, kenyataannya lanjut usia sebenarnya dapat berdaya sebagai subyek dalam pembangunan kesehatan, sosial, ekonomi dan budaya. Dalam Artikel Lansia yang dikeluarkan oleh Kementerian Kesehatan RI tahun 2016 diterangkan bahwa dari banyak kasus tentang pengalaman hidup dan peran lanjut usia, mereka bukan hanya sebagai orang yang dituakan dan dihormati di lingkungannya, tetapi juga dapat berperan sebagai agen perubahan (agent of change) di lingkungan keluarga dan masyarakat sekitarnya dalam mewujudkan keluarga sehat, dengan memanfaatkan pengalaman yang sudah dimiliki dan diperkaya dengan pemberian pengetahuan kesehatan yang sesuai.

Tingginya jumlah usia harapan hidup Iansia saat ini merupakan salah satu keberhasilan dari program kependudukan ${ }^{4}$ dalam menurunkan tingkat fertilitas ${ }^{5}$ dan mortalitas ${ }^{6}$ serta meningkatnya usia harapan hidup. Artinya perubahan dalam transisi demografi ini sejalan dengan proses pembangunan nasional yang bertujuan untuk meningkatkan kesejahteraan masyarakat secara tidak langsung, yang menyebabkan perubahan struktur umur penduduk.

Melihat kepada perubahan struktur umur penduduk sekarang ini, terlihat bahwa jumlah perempuan lansia yang memiliki usia harapan hidup tinggi dan masih bekerja di usia lebih tua, khususnya perempuan lansia mandiri, walaupun kemandirian itu tidak bisa dilihat secara keseluruhan tetapi bisa dilihat dari segi kebutuhan ekonomi di dalam keluarga atau rumah tangga. Jika melihat kepada kemandirian seseorang, secara tidak langsung juga melihat kepada kebutuhan dan pekerjaan. Persepsinya adalah berkaitan dengan kepuasaan terhadap posisi dan keadaan lanjut usia di dalam kehidupan yang cenderung dipengaruhi oleh sejauh mana tercapainya kebutuhan ekonomi

\footnotetext{
${ }^{4}$ Salah satu program kependudukan yang berhasil meningkatkan jumlah penduduk lansia dengan adanya Keluarga Berencana (KB), Bina Keluarga Lansia (BKL) sebagai satu aset atau potensi untuk pembangunan. Kemudian adanya Posyandu Lansia, Jaminan Sosial Lansia, Program Pendamping Jaminan Sosial Lansia, Pelayanan Harian Lansia dan sebagainya.

${ }^{5}$ Fertilitas adalah istilah demografi diartikan sebagai hasil reproduksi yang nyata dari seseorang wanita atau sekelompok wanita. Dengan kata lain fertilitas menyangkut banyaknya bayi hidup yang lahir.

${ }^{6}$ Mortalitas adalah ukuran jumlah kematian (umunya, atau karena akibat yang spesifik) pada suatu populasi, skala besar suatu populasi per dikali satuan.
} 

dalam kehidupan rumah tangga atau keluarga.

Khususnya penelitian ini melihat kepada perempuan Jawa yang terkadang sering dikaitkan dengan peran dan tanggung jawab di sektor domestik, sehingga mereka mempunyai peran sebagai ibu dan istri yang berada tidak jauh dengan kegiatan dapur, kasur dan sumur dalam keseharian mereka. Dalam buku Permanadeli (2015) yang menunjukkan bahwa perempuan Jawa memiliki posisi penting dalam struktur kehidupan rumah tangga di Jawa, dengan mendefinisikan ruang domestik sebagai aktifitas perempuan Jawa sehari-hari, dimana sistem sosial Jawa melihat berdasarkan nilai dan norma kebudayaannya yang melekat ke dalam hidup dan ruang mental individual maupun secara sosial. Menurut Pudjianto (2017) keterkaitan perempuan dengan ruang domestik atau dapur kerap disalahartikan dengan memandang posisi perempuan sebagai orang terbelakang. Justru sebaliknya dapur merupakan sebuah ruang paling menentukan kehidupan keluarga pada budaya Jawa, dari dapur seorang perempuan dikenalkan dan mengenal ungkapan srawung sebagai identitas untuk dikenal secara sosial sebagai seorang perempuan Jawa dan ungkapan wong wedok kuwi kudu srawung yang berarti perempuan harus bisa menyatukan diri dengan dunia Jawa yakni pandai dan mampu bergaul.

Permasalahan kemandirian lansia yang bekerja khususnya perempuan dapat dikatakan begitu beragam pandangan dari berbagai budaya di dalam masyarakat. Hal ini telah ditunjukan dari beberapa kajian yang dilakukan oleh ilmuwan, peneliti dari berbagai latar belakang dan berbagai daerah. Kajian ini bermaksud mengemukakan yang berbeda dari beberapa kajian lain, berupa kejadian fakta kemadirian ekonomi perempuan lanjut usia yang bekerja untuk menghidupi hidupnya sendiri dan menjadi tulang punggung keluarga atau rumah tangga anak dan cucu, karena sebagian dalam lingkup masyarakat di Indonesia masih menganggap tabu bagi perempuan yang bekerja selain dalam ranah domestik. Sehingga Uraian ini dapat memperlihatkan bahwa perempuan memiliki tanggung jawab yang besar dan dapat bekerja dalam segala ranah pekerjaan, tidak hanya bagi perempuan usia produktif tetapi juga usia non produktif. Oleh sebab itu, perumusan masalah ini melihat bagaimana perempuan di usia yang sudah lanjut dapat survive dan menjadi backbone of the family serta masih dapat bertanggung jawab dengan lingkungan sosial. Tulisan ini memiliki tujuan positif untuk penduduk Indonesia agar dapat memberikan peluang kerja yang lebih bagi perempuan, tidak hanya bagi perempuan yang berusia produktif tetapi juga kepada usia non produktif juga. Karena sekarang ini kehidupan yang semakin berkembang, bukan dan sosial, serta perkembangan lanjut usia

saja laki-laki yang memberi nafkah kepada keluarga tetapi perempuan juga ikut serta memiliki tanggung jawab yang lebih dalam pemberi nafkah dikeluarga. Sehingga kita harus lebih peduli terhadap kehidupan perempuan, apalagi dengan kondisi perempuan lansia yang sudah berstatus janda dan memiliki anak serta cucu yang menjadi penafkah keluarga atau rumah tangga.

\section{B. METODE PENELITIAN}

$\mathrm{P}$ enelitian ini menggunakan metode etnografi dengan pendekatan kualitatif (Spradley, 2006) untuk memahami suatu pandangan hidup dari sudut pandang masyarakat setempat. Penggunaan metode ini berkenaan dengan penelitian yang berfokus pada studi etnografi masyarakat lansia di desa Demuk. Tujuan penggunaan metode etnografi dalam penelitian ini untuk menganalisis aktivitas dan kegiatan lansia khususnya perempuan lansia di pedesaan yang berhubungan dengan kemandirian ekonomi yaitu dengan melihat kehidupan perempuan lansia berstatus janda yang bekerja dalam ranah domestik dan pertanian, serta mengenai keberlangsungan hidup menjadi tulang punggung keluarga atau rumah tangga dan dirinya sendiri. Dasar pertimbangan peneliti menggunakan metode etnografi adalah untuk mencari tahu tentang kebudayaan dari kelompok berkebudayaan yang berbeda, dengan itu dapat menganalisis data peneliti bersandarkan pada pandangan dari pada partisipasi dari hasil observasi dan wawancara informan penelitian

\section{HASIL DAN PEMBAHASAN 1. Gambaran Umum}

$\mathrm{D}$ esa Demuk merupakan salah satu bagian dari Sejarah sembilan desa yang terletak di wilayah administrasi Kecamatan Pucanglaban, Kabupaten Tulungagung. Desa Demuk yang merupakan cikal bakal (sesepuh yang mula-mula mendirikan Kecamatan Pucanglaban) yang terletak kurang lebih $30 \mathrm{~km}$ arah Tenggara dari kota Tulungagung. Meskipun desa terpencil yang letaknya di dataran tinggi pegunungan kapur, namun tidak ketinggalan turut menghiasi lembaran sejarah kota Tulungagung.

Desa Demuk berada di Provinsi Jawa Timur yang menurut data BPS $^{7}$ persentase lansia terbanyak yaitu 11,80 persen. Desa ini terbagi atas 4 dusun $9 \mathrm{RW}$ dan $55 \mathrm{RT}$ dengan jumlah

\footnotetext{
${ }^{7}$ Badan Pusat Statistik (BPS) dan Survei Sensus Ekonomi Nasional (Susenas) 2016, merupakan kegiatan survei untuk mengumpulkan informasi/data di bidang kependudukan, kesehatan, pendidikan, keluarga berencana, perumahan, serta konsumsi dan pengeluaran, yang sangat dibutuhkan oleh berbagai kalangan.
} 
penduduk terbanyak di kecamatan Pucanglaban \pm 6187 orang, dimana sebagian besar penduduknya adalah perempuan $( \pm 3251)$.

Hasil data Badan Pusat Statistik (BPS) Tulungagung Kecamatan Pucanglaban dalam Angka tahun 2017 menyatakan bahwa desa Demuk merupakan salah satu desa yang sukses, berhasil dan memiliki kesejahteraan yang bagus, baik itu dalam hal sosial (nilai gotong royong yang tinggi dengan kepala desa yang turun langsung melihat kondisi desa) dan agama (memiliki 7 Masjid dan 31), pertanian (Padi $234 \mathrm{Ha}$, Jagung $735 \mathrm{Ha}$, Ubi kayu $59 \mathrm{Ha}$, Kacang tanah $4 \mathrm{Ha}$ ), maupun keuangan (Pemasukan Rp.1,562,338,094; Pengeluaran Rutin Rp.888,083,094; dan Pengeluaran Rp.674,255,000) dan jasa-jasa (Persewaan Alat Pesta ada 4 tempat, Reparasi motor ada 4 tempat, sepeda ada 1 tempat dan elektronik ada 4 tempat, las/bubut 2 tempat, bilyard ada 1 tempat, penjahit ada 4 orang, tambal ban ada 6 tempat dan tukang kursi ada 1 tempat). Walaupun sebagian dari penduduk di desa tersebut bekerja di luar desa sebagai Tenaga Kerja Indonesia (TKI) atau Tenaga Kerja Wanita $(\mathrm{TKW})^{8}$.

\section{Hasil Penelitian}

Penelitian ini bertujuan untuk mengetahui bagaimana kemandirian ekonomi lanjut usia dengan melihat kehidupan perempuan lansia dari aktivitas mereka. Secara umum dalam penentuan kategori lansia di desa Demuk, masyarakat desa Demuk memiliki pandangan tersendiri mengenai kriteria lansia dibanding kriteria dari Dinas Sosial. Sebab pengertian lanjut usia bagi orang Jawa khususnya bagi masyarakat di desa Demuk adalah lebih mengedepankan kriteria sosial dari kehidupan lansia tersebut seperti dengan adanya kelahiran cucu pertama yang kemudian menjadi penanda bahwa mereka sudah menjadi tua, atau dengan sebutan Mbok dan Mbah (nenek).

\section{a. Kategori Usia dan Jenis Kelamin Lansia}

Berdasarkan penelitian WHO pada tahun 2016, bertambahnya penduduk lansia itu adanya perkembangan struktur tua dan pertumbuhan penduduk lansia yang semakin lama jumlah penduduknya semakin meningkat, dikarenakan pertumbuhan jumlah penduduk lansia sering dikaitkan dengan Umur Harapan Hidup $(\mathrm{UHH})^{9}$. Artinya semakin meningkatnya Umur Harapan Hidup (UHH) berarti terjadinya peningkatan jumlah penduduk lansia yang diasumsikan akan mempertinggi rasio ketergantungan terhadap

\footnotetext{
${ }^{8}$ BPS Tulungagung, kecamatan Pucanglaban dalam angka 2017.

${ }^{9}$ Harapan hidup saat lahir diartikan jumlah tahun yang dapat diharapkan seseorang untuk hidup. Angka harapan hidup perempuan empat tahun lebih lama dibandingkan laki-laki, yaitu 72 tahun perempuan dan 68 tahun laki-laki.

14 | P a g e

RICHA MELIZA
}

penduduk produktif. Pertumbuhan jumlah penduduk lansia yang relatif cepat merupakan kondisi yang harus dihadapi disebabkan penduduk lansia di Indonesia seperempat jumlahnya adalah tergolong penduduk lansia. Di wilayah Asia Tenggara sendiri, Indonesia merupakan negara yang jumlah penduduk lansia paling banyak walaupun secara persentase penduduk lansia di Singapura, Thailand dan Vietnam angkanya lebih tinggi ${ }^{10}$.

Dalam hal kategori usia dari segi jenis kelamin menurut hasil survei yang dilakukan oleh Badan Pusat Statistik Indonesia, setiap tahunnya usia harapan hidup antara perempuan dan lakilaki terlihat berbeda. Data survei per tahun di setiap provinsi, memperlihatkan hasil angka harapan hidup yang berbeda antara perempuan dan laki-laki yang terpaut empat tahun, rata-rata angka harapan hidup perempuan 73 tahun dan laki-laki-laki 69 tahun. Harapan hidup perempuan lebih tinggi dibandingkan laki-laki, bukan tidak memiliki alasan tersendiri melainkan mempunyai tiga faktor utama yaitu makanan, lingkungan (ekologi maupun sosial) dan tingkat stres. Sehingga jika dilihat dari ketiga faktor tersebut, yang membedakan antara keduanya adalah tingkat stres. Karena dalam suatu kelompok masyarakat antara perempuan dan laki-laki secara umum dapat dikatakan bahwa mereka makan makanan yang relatif sama, demikian pula dengan lingkungan yang hampir bisa dikatakan sama, tetapi yang membedakan adalah tingkat stres pada seseorang.

Secara logis tingkat stres yang berkaitan dengan harapan hidup laki-laki umumnya rendah dibandingkan perempuan. Tetapi tidak dapat dipungkiri bahwa perempuan juga memiliki beban secara fisik yang lebih besar, karena perempuan itu mempunyai peran ganda dalam keluarga atau rumah tangga, yaitu sebagai pencari nafkah dan sebagai ibu rumah tangga yang harus melayani kebutuhan keluarga yang sering kali harus bekerja lebih berat daripada suami. Akhirnya terkadang pekerjaan perempuan hanya dikaitkan dengan pekerjaan domestik. Sedangkan laki-laki dikaitkan pada pekerjaan publik. Tetapi pada kenyataannya perempuan mempunyai beban yang lebih banyak dibandingkan laki-laki. Seperti potensi pekerjaan yang dimiliki perempuan lebih tinggi dibandingkan laki-laki, salah satunya adalah fungsi perempuan dalam sebuah keluarga atau rumah tangga. Dalam sebuah keluarga atau rumah tangga, adakalanya perempuan pra lanjut usia maupun lanjut usia mempunyai potensi pekerjaan menjadi tulang punggung keluarga, mengurusi anak, suami, cucu, dan lainnya. Para perempuan yang bekerja seringkali mereka memulai harinya dari pagi sampai siang hari,

\footnotetext{
${ }^{10}$ Data prediksi BPS yang menyatakan pada tahun 2045 penduduk Indonesia akan mencapai sekitar 450 juta jiwa, maka pada tahun 2050 jumlah penduduk di Indonesia 100 juta jiwa.
} 
kemudian dilanjutkan dengan pekerjaan domestik. Sedangkan laki-laki setelah lelah bekerja diluar rumah kemudian tidak memiliki kegiatan lagi selain bersantai. Oleh sebab itu, kategori penetapan usia berbeda antara laki-laki dan perempuan.

Dalam penetapan usia lanjut usia tidak hanya dilihat dari usia 65 tahun atau lebih, tetapi banyak yang berpendapat bahwa lanjut usia itu dilihat dari kondisi kesehatan dan lebih melihat kepada kehadiran cucu pertama di dalam sebuah keluarga. Pada dasarnya, penetapan usia bagi lanjut usia memiliki ukuran yang berbeda-beda dan sesuai dengan anggapan terhadap nilai-nilai tertentu pada suatu daerah. Angka harapan hidup perempuan di desa Demuk lebih tinggi dibandingkan dengan laki-laki karena pola hidup yang tidak teratur yaitu faktor kesehatan dan jenis pekerjaan yang berbeda antara laki-laki dan perempuan, sehingga menyebabkan tingkat harapan hidup perempuan lebih tinggi.

Tabel .1. Kelompok Umur dan Jenis Kelamin Lanjut Usia

\begin{tabular}{ccccc}
\hline No & Umur & \multicolumn{2}{c}{ Jenis Kelamin } & Keterangan \\
\hline 1. & 60-65 Tahun & 115 & Perempuan & Lansia \\
2. & $70-75$ Tahun & 261 & 201 & Lansia \\
3. & $80-85$ Tahun & 55 & 103 & Lansia \\
4. & \pm 90 tahun & 9 & 11 & Lansia berumur panjang \\
\hline \hline & Jumlah & $\mathbf{4 4 0}$ & $\mathbf{6 1 0}$ &
\end{tabular}

Berdasarkan tabel kelompok umur dan jenis kelamin diatas dapat dilihat bahwa angka lansia yang menunjukkan usia 65 tahun atau lebih memiliki perbedaan antara jumlah laki-laki dan jumlah perempuan. Walaupun dalam kehidupan di suatu daerah nyatanya dari usia 50 tahun atau lebih sebagian besar menganggap diri mereka sudah lanjut usia karena kondisi sosial yang menandakan bahwa kelahiran cucu pertama didalam keluarga merupakan perubahan secara otomatis dan langsung bagi orang tua menjadi menua atau lanjut usia. Sehingga pengertian lanjut usia itu sendiri dari hasil penelitian ini tidak dapat diartikan sebagai seseorang yang tidak berdaya dalam mencari nafkah sendiri untuk keperluan hidupnya sehari-hari dan menerima nafkah dari orang lain. Melainkan dapat dilihat dari proses dan keragaman budaya, karena itu adalah sesuatu yang kompleks dari aktivitas dan tindakan yang berpola dalm masyarakat. Melihat kepada pandangan masyarakat tentang batasan usia, baik itu pandangan bagi lanjut usia maupun masyarakat sekitar dan keluarga. Sebab setiap masyarakat mempunyai keragaman budaya masing-masing dan mempunyai pendapat sendiri terhadap pemahaman kata lanjut usia.

\section{b. Perempuan}

Dalam keberadaannya di tengah-tengah masyarakat, perempuan tidak luput dari berbagai sudut pandang yang menyertai kehidupan mereka. Masyarakat mengartikulasikan bahwa perempuan berdasarkan sudut pandang dari perannya dalam masyarakat, keluarga atau rumah tangga dan pendidikan. Pada kenyataannya perempuan menurut pandangan sejarah memainkan banyak peran dalam kehidupannya. Perempuan bisa sebagai ibu, istri, pengelola rumah tangga, pekerja seorang petani dan sebagainya. Kaum perempuan sekarang ini menjadi sorotan, bukan hanya karena harapan hidup para perempuan yang lebih tinggi dari pada laki-laki tetapi adanya masalah gender dalam hal bekerja untuk memenuhi kebutuhan ekonomi rumah tangga serta hambatan materi yang berupa rendahnya tingkat pendidikan dan keterampilan sebagai besar perempuan dan rentannya posisi perempuan (dan anak-anak) dalam masyarakat, sehingga apabila masyarakat miskin, maka perempuan dan anak-anak yang paling berat menanggung akibatnya. Tentu salah satunya perempuan lansia yang akan merasakan dan menghadapi permasalahan kesejahteraan dalam hidup dari permasalahan ekonomi ini.

Sama halnya dengan kedudukan perempuan di Bali, dalam tulisan Lestari dkk (2016) menyatakan bahwa perempuan Bali itu memiliki kedudukan yang terhormat dalam masyarakat Bali. Tidak hanya menjadi perempuan yang berperan dalam ranah domestik namun juga mengambil peran yang bermakna dalam kehidupan bermasyarakat. Sehingga perempuan Bali dan Jawa, dimana mempunyai sistem kekeluargaan yang sama yaitu patrilineal akan membawa konsekuensi bagi peran dan kedudukan di dalam keluarga. Perempuan akan menjadi tolak ukur keberhasilan sebuah keluarga dan akan membawa kegenerasi selanjutnya. 
Perempuan sangat memiliki ketelatenan dalam melakukan segala hal baik di ranah domestik dan publik sehingga menurut Jannah (2016) dalam menyingkapi lansia perempuan yang memilih bekerja adalah guna untuk memenuhi kebutuhan hidup, mampu berdiri sendiri dan mampu menghadapi segala bentuk keadaan bahkan ancaman yang sulit dalam kehidupannya. Semuanya itu merupakan pilihan lansia dalam memenuhi kebutuhan ekonomi, mengisi waktu luang dan membangun hubungan sosial dengan lingkungan sekitar. Selanjutnya menurut Lestari (2017) yang melakukan kajian di Provinsi yang sama yaitu Daerah Istimewa Yogyakarta, beliau mengatakan bahwa faktor yang mempengaruhi lanjut usia tetap bekerja adalah keadaan fisik yang mendukung, kondisi ekonomi yang kurang mampu, tuntutan untuk memenuhi kebutuhan hidup, dorongan tetap mandiri dan kurangnya bantuan anak. Serta menurut Sari (2016) dalam kajiannya mengungkapkan bahwa terdapat dua faktor yang mempengaruhi motivasi kerja pada lansia yaitu secara internal dan eksternal. Secara internal bekerja merupakan suatu kegiatan untuk menyenangkan diri sendiri, media hiburan dan kegiatan yang mereka lakukan selama kondisi fisik mereka masih mampu untuk bekerja. Sedangkan secara eksternal bekerja sebagai kegiatan untuk menjalani hubungan dengan orang lain dan kegiatan untuk mendapatkan peranan di tengah kelompok lingkungannya.

Secara umum masyarakat dalam lingkungan yang masih mempunyai stereotipe terhadap perempuan, yang segala sesuatu dilihat dari jenis kelamin dan pekerjaan, masih dianggap tabu dan tidak sesuai kodrat, seperti pada masalah pekerjaan diluar domestik biasanya dengan lakilaki yang menganggap semuanya itu adalah suatu permasalahan, tetapi kecenderungan masyarakat sekarang ini, menurut Suartha (2015) bahwa perempuan bekerja merupakan potensi yang kuat untuk meningkatkan pendapatan ekonomi keluarga. Secara kultur Jawa, perempuan yang bekerja adalah hal lumrah sejalan dalam kehidupan yang memiliki peran ganda dan dapat bertanggung jawab dengan keluarga dan lingkungan masyarakat. Seperti yang diungkapkan kembali oleh Suartha (2015), bahwa dalam sektor atau permasalahan ekonomi didalam hidup yang paling potensial akan melibatkan peran dan kesertaan kaum perempuan terutama dalam hal sektor informal. Sektor informal adalah sektor yang paling fleksibel dalam menerima keluar masuknya pekerja, dalam artian sektor ini tidak membutuhkan persyarakatan formal dan sangat terbuka bagi setiap individu sepanjang individu tersebut memiliki kemampuan dan kemauan. Dalam hal ini sesuai dengan perempuan lanjut usia yang bekerja, yang memiliki keterbatasan dan kelemahan tetapi masih menginginkan tetap berdaya, produktif dan aktif untuk memenuhi kebutuhan ekonomi keluarga atau rumah tangga.

Seperti permasalahan kemandirian ekonomi pada perempuan, khususnya perempuan lansia daerah Tulungagung, desa Demuk, Jawa Timur. Disebuah desa terpencil yang terletak di daratan pegunungan gamping dekat perbatasan dengan Blitar Selatan. Populasi angka harapan hidup yang tinggi dari tahun 2009 sebesar 71,23\% dan tahun 2013 sebesar 72,09\%. Sedangkan berdasarkan pada data BPS Tulungagung pada tahun 2014, jumlah penduduk sebanyak 1.053.276 jiwa, tercatat laki-laki sebanyak 526.188 jiwa, sedangkan perempuan sebanyak 527.088 jiwa $^{11}$. Perempuan di daerah Tulungagung merupakan salah satu penyumbang Tenaga Kerja Indonesia (TKI) dan Tenaga Kerja Wanita ( TKW) yang cukup besar di Indonesia. Di kabupaten ini, banyak penduduk usia produktif yang bekerja di luar negeri menjadi TKI dan TKW.

Kemudian peneliti menemukan bahwa perempuan lansia bekerja di ranah domestik menjadi ibu serta nenek untuk mengurusi anak dan cucu dari segala hal, baik secara sosial dan ekonomi tetapi tetap juga bekerja sebagai petani karena bagi perempuan yang masih produktif merasakan tidak lagi menjanjikan bagi mereka bekerja di desa sebagai petani, mereka membutuhkan penghasilan lebih untuk mencukupi keluarganya sehingga bekerja di luar negeri. Sehingga tenaga kerja di sektor pertanian lebih banyak di dominasi oleh para orang tua. Bekerja di sektor lain menjadi sangat kesulitan bagi masyarakat atau lanjut usia karena kurangnya keahlian dan rendahnya tingkat pendidikan yang mereka miliki. Oleh karena itu, wajar kiranya daerah ini menjadi salah satu daerah di Indonesia yang menjadi sumber TKI dan TKW untuk pergi ke luar negeri.

\section{c. Mata Pencaharian Perempuan Lansia}

Di negara berkembang dengan jumlah anggota didalam rumah yang mempunyai banyak orang dalam satu atap atau satu rumah walaupun tidak dalam satu kartu keluarga (KK) maka akan meningkatkan kebutuhan finansial maupun kebutuhan ekonomi di dalam suatu keluarga. Dipertegas ungkapan dari Padmiati dan Diyanayati (2015) terutama di daerah pedesaan pada umumnya lansia menikmati hari tuanya di lingkungan keluarga, dalam sebuah rumah tangga (keluarga) terkadang terdiri dari tiga bahkan sampai empat generasi.

Indonesia masih banyak lanjut usia yang masih menanggung kehidupan anak-anak maupun cucu-cucunya meskipun sudah berkeluarga. Berdasarkan data BPS 2014 mencatat bahwa hampir setengah dari jumlah lanjut usia $(47,48$ persen) masih bekerja untuk

${ }^{11}$ http://tulungagung.go.id 
memenuhi kebutuhan hidup dan keluarganya, mereka menjadi tulang punggung dalam hal memenuhi ekonomi keluarga atau rumah tangga. Masih banyak lanjut usia yang memberikan modal usaha untuk anak-anaknya maupun cucunya yang sudah berkeluarga dalam bentuk materi, tanah, rumah atau dalam hal lainnya yang mereka miliki untuk kebutuhan hidup mereka. Kebanyakan dari para lanjut usia yang masih bekerja di masa tua dapat hidup mandiri dalam hal ekonomi, walaupun kemandirian itu tidak dapat dilihat secara keseluruhan tetapi dalam hal ekonomi mereka dapat survive. Salah satu kasus seseorang yang memiliki kemandirian dalam hal ekonomi yaitu para perempuan janda yang di tinggal meninggal sejak lama oleh suaminya sehingga mereka harus menafkahi dirinya sendiri serta anak-anaknya. Dalam stigma masyarakat budaya ketimuran, kaum janda dilihat sebagai perempuan yang lemah, tidak berdaya, beban keluarga sehingga mereka harus menjaga harkat dan martabat dirinya sendiri di tengah-tengah stigma negatif tersebut (Sakina dan Siti A; 2017).

Belakangan ini, menurut hasil persentase konon cukup banyak perempuan termasuk kedalam angka kerja global, seperti pada tahun 2017 sebesar 39,289 persen, apalagi perempuan lansia berstatus janda yang bekerja. Beberapa dari para perempuan janda ini penyebabnya adalah akibat dari tingkat kematian dan perceraian yang sangat tinggi di desa maupun kota. Sehingga jika dilihat masyarakat di desa khususnya Demuk yang sebagian besar perempuan lansia bekerja secara domestik dan mempunyai mata pencaharian yang beragam, tetapi mata pencaharian yang paling banyak dilakukan oleh masyarakat desa Demuk adalah petani, manjing (buruh), peternak dan pedagang. Hal ini terlihat dari banyaknya persawahan yang membentang luas di setiap dusun yang ada di desa Demuk dan terdapat beberapa pasar, baik pasar sandang, pangan dan juga barang-barang lain.

Di desa Demuk terdapat pasar yang berada di persimpangan empat yang bisa didatangi dari dusun Gajah Oyo, Rowoangung, dan Demuk yaitu pasar yang hanya dibuka pada hari selasa wage. Menurut masyaraakat pasar tersebut hanya dibuka pada hari selasa wage, karena memiliki tujuan agar masyarakat bisa mengingat hari itu saja agar tidak terlupakan, sebab jika menggunakan tanggal atau hanya hari biasa masyarakat takut orang yang sudah lanjut usia atau orang tua yang tidak bisa membaca dan melihat kalender tanpa mengetahui hari pasar tersebut, sehingga masyarakat menggunakan hari Jawa untuk menentukan hari pasar tersebut.

Adapun jenis-jenis mata pencaharian masyarakat desa Demuk yang didapat dari hasil wawancara dan dokumen desa.

Tabel 2. Jenis-Jenis Mata Pencaharian Penduduk Desa Demuk

\begin{tabular}{ccc}
\hline No & Jenis Mata Pencaharian & Jumlah Penduduk \\
\hline 1. & Petani & 970 \\
2. & Buruh Tani & 316 \\
3. & Buruh Pabrik & 95 \\
4. & Pedagang & 43 \\
5. & Pengrajin dan Produksi & 16 \\
6. & Peternak & 25 \\
7. & Montir & 16 \\
8. & Pertukangan & 20 \\
9. & Penjahit & 15 \\
10. & Guru & 25 \\
11. & TNI dan Polri & 7 \\
12. & PNS dan Pensiunan & 139 \\
\hline & & 1687 \\
\hline & Jumlah
\end{tabular}

Selain dari jenis pekerjaan yang tertulis diatas, di desa Demuk juga terdapat banyak kegiatan kemasyarakatan yang sebagian besar dikerjakan oleh perempuan yang memiliki jangka waktu pelaksanaan yang berbeda-beda.
Sehingga terlihat komposisi penduduk lanjut usia yang perempuan bekerja, walaupun pekerjaan mereka hanya sebagai besar petani atau buruh tani. Dapat digambarkan dengan diagram sebagai berikut: 
Diagram 1. Persentase Pekerjaan Pada Perempuan Lanjut Usia

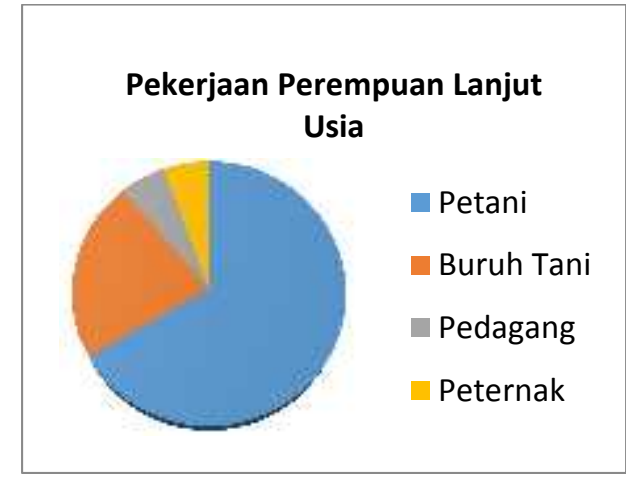

Sumber: Hasil Survei Penelitian Tahun 2018

Berdasarkan pada diagram diatas diketahui bahwa sebagian besar penduduk perempuan lansia bekerja sebagai petani, dikarenakan sebagian besar mereka tidak memiliki tamatan pendidikan dan keahlian lain yang mereka miliki. Mereka dari masa kecil sampai sekarang hanya diajarkan proses bertani oleh orangtua mereka. Bertani adalah pekerjaan yang sangat memungkinkan bagi mereka untuk bertahan hidup di desa walaupun desa yang memiliki tandas kering yang bisa bisa ditanami tani dalam setahun sekali, setelah itu masyarakat bercocok tanam tanaman yang lain seperti jagung, ketela, kacang-kacangan dan lain-lain.

Selain itu beragam kegiatan baik itu yang mingguan, bulanan, dan ada juga kegiatan yang tahunan, yaitu pengajian rutinan, peringatan hari raya besar Islam dan nasional, arisan kelompok (arisan balai desa maupun arisan dari Program Keluarga Harapan), tabungan hari raya, PKK, Koperasi wanita,Tahlilan dari rumah ke rumah, simpan pinjam, Posyandu, dan bersih-bersih desa. Seperti dibawah ini merupakan sebagian dari salah satu kegiatan yang ada di desa Demuk.

\section{Foto 1. Kegiatan Perempuan Lansia di Desa Demuk}

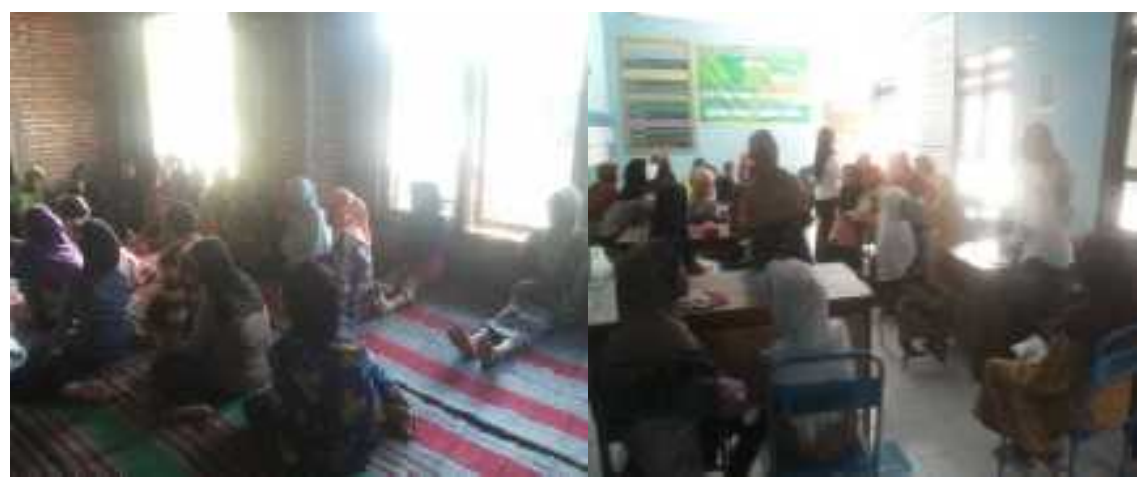

Ini adalah salah satu kegiatan yang ada di desa Demuk yaitu, arisan lanjut usia (sebelah kiri) dan Posyandu lanjut usia (sebelah kanan) yang diadakan di rumah warga dan balai desa. Sumber: Richa Meliza (30 Mei 2018 pkl. 10.02 WIB)

Beberapa kegiatan yang ada di desa Demuk sebagian besar diikuti oleh perempuan lanjut usia (Keterangan: lihat foto 1.). Sedikit banyaknya kegiatan tersebut memberikan sumbangan ilmu bagi para masyarakat desa Demuk khususnya bagi perempuan lanjut usia untuk selalu mengikuti perubahan yang akan terjadi kedepannya serta dapat membedakan yang mana positif dan negatif serta untuk memperpanjang silaturrahmi antar masyarakat. Seperti dalam halnya arisan, tabungan hari raya itu sangat bermanfaat bagi para perempuan baik itu lansia atau pralansia. Walaupun mereka hanya menyimpan uang sebulan sekali hanya Rp.5000 tetapi itu sangat berharga bagi mereka untuk kedepannya. Sehingga terlihat bagaimana sebagian kehidupan para lanjut usia sehari-hari di desa Demuk.

Oleh karena itu, para perempuan lansia mempunyai fungsi menjadi tulang punggung serta mempunyai peran ganda dalam keluarga atau rumah tangga untuk memenuhi kebutuhan dirinya sendiri, anak, cucu yang berada dalam struktur keluarga. Mereka bekerja dalam ranah domestik dan bekerja sebagai petani serta buruh untuk kebutuhan ekonomi keluarga atau rumah tangga untuk konsumsi, membayar listrik dan air, serta untuk menambah modal pekerjaan sendiri di ladang maupun modal untuk anak-anaknya membuka usaha untuk kerja. Sehingga ini dapat 
dikaitkan dengan teori yang sudah ada seperti pendekatan struktural-fungsionalisme, melihat kepada fungsi perempuan khususnya lansia dalam struktur keluarga dan bagaimana ekonomi perempuan lansia berfungsi dalam keluarga yang mengakibatkan adanya kemandirian ekonomi dalam memenuhi kehidupan dirinya sendiri dan keluarga atau rumah tangga. Rumah tangga adalah satuan tempat tinggal yang berorientasi pada tugas, sedangkan keluarga adalah pengelompokan kerabat yang tidak harus tinggal di satu tempat. Sehingga rumah tangga adalah fungsional ekonomi-kegiatan produktif, konsumsi, distribusi dalam upaya memenuhi kebutuhan hidup.

Berkaitan dengan kemandirian ekonomi perempuan, khusunya kehidupan perempuan lansia yang memiliki peran ganda dalam rumah tangga atau keluarga sehingga mereka mempunyai fungsi lebih perempuan lansia dalam struktur keluarga atau rumah tangga dengan melihat kemandirian ekonomi dalam memenuhi kebutuhan hidup. Karena dalam kehidupan secara realitas para perempuan yang sudah lansia tidak lagi memikirkan anak-anak maupun cucunya yang sudah usia produktif karena sudah bisa mencari pekerjaan dan mendapatkan penghasilan untuk memenuhi kebutuhan hidup. Tetapi kenyataan para lansia khususnya perempuan lansia di pedesaan masih berfungsi untuk bekerja dalam struktur keluarga atau rumah tangga serta menghasilkan uang bagi dirinya sendiri dan keluarga atau rumah tangga untuk konsumsi atau upaya memenuhi kebutuhan lainnya. Sehingga para perempuan lansia itu dapat hidup mandiri secara ekonomi dan tidak menjadi beban orang lain melainkan menjadi tulang punggung keluarga atau rumah tangga serta menjadi penunjang ekonomi untuk kebutuhan anak dan cucu. Seperti salah satu contoh kasus perempuan lansia yang memiliki peran ganda dan menjadi hidup mandiri untuk memenuhi kebutuhan dalam keluarga atau rumah tangga. Di bawah ini salah satu informan dalam penelitian yang merupakan perempuan lanjut usia, masih bekerja, dan menjadi tulang punggung keluarga atau rumah tangga.

\section{d. Kasus Mbah Katini}

Disaat usia para lansia yang semakin menua, para lansia menunjukkan bahwa mereka tidak lemah, mereka bukanlah beban dari keluarga maupun masyarakat. Tetapi mereka adalah perempuan yang ingin maju, berjuang untuk dirinya sendiri dan keluarga. Dalam tulisan ini menjelaskan satu kasus perempuan lansia yang menurut peneliti mempunyai kehidupan ekonomi yang begitu menarik dan menjadi inspirasi banyak orang, dari beberapa informan yang pernah peneliti kunjungi selama penelitian di lapangan, peneliti tertarik dengan kehidupan kemandirian ekonomi para lansia. Di bawah ini, kasus seorang perempuan lansia yang tangguh dan mandiri dalam menjalani lika-liku dalam kehidupan dirinya dan memenuhi kebutuhan ekonomi keluarga atau rumah tangga.

\section{Foto 2. Disaat Sedang Mewawancarai Mbah Katini}

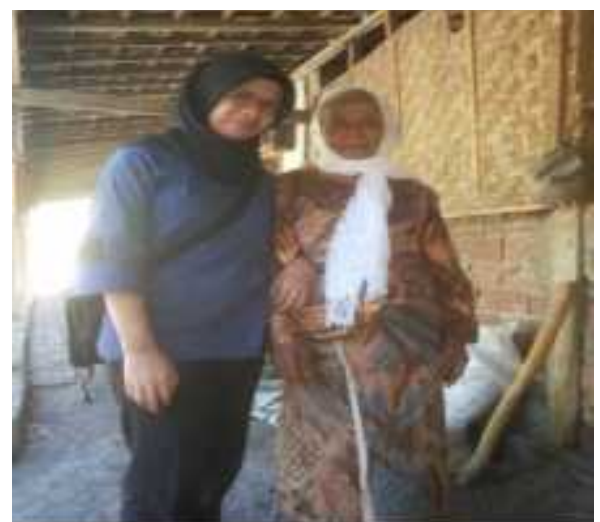

Salah satu informan yang bernama mbak Katini (79 tahun), seorang janda yang di tinggal meninggal oleh suaminya, yang sekarang bekerja sebagai seorang petani, buruh tani dan pembuat kerupuk mantenan di desa Demuk. Sumber: Richa Meliza (14 Juni 2018 pkl. 09.37 WIB)

Foto di atas merupakan salah satu dari sebagian besar perempuan lanjut usia yang statusnya seorang janda yang ditinggal meninggal oleh suaminya sejak anak-anaknya masih kecil. Sekarang beliau sudah berumur 79 tahun mempunyai peran ganda dalam keluarganya. Beliau masih bekerja sebagai petani, buruh, pembuat kerupuk mantenan dan menjadi orang tua dari anak dan cucunya serta sekarang ini menjadi tulang punggung anak dan cucunya karena kondisi ekonomi yang sulit.

Beliau mempunyai tiga orang anak, diantaranya dua orang anak laki-laki dan satu orang perempuan. Dimana salah satu dari anaknya adalah disabilitas yang masih tinggal bersama dalam satu atap serta menjadi tanggung jawab mbah Katini dalam memenuhi semua kebutuhannya. Sedangkan anaknya yang 
lain sudah menikah dan mempunyai anak tetapi masih tinggal bersama dengan beliau karena belum memiliki pekerjaan yang tetap dan belum memiliki tempat tinggal sendiri.

Kegiatan keseharian mbah Katini adalah mengerjakan pekerjaan rumah seperti memasak, menyuci, menjaga anaknya yang disabilitas setelah itu bekerja di ladang, menjadi buruh tani, peternak sapi dan kambing kemudian mengikuti arisan lansia yang diadakan oleh pendamping Program Keluarga Harapan (PKH). Semuanya kegiatan dan aktivitas tersebut dikerjakan seorang diri oleh si mbah Katini, tetapi terkadang jika kondisi tubuh yang kurang sehat, beliau dibantu oleh anak laki-lakinya dalam mengerjakan segala hal.

Dalam hal pendapatan ekonomi mbah Katini dalam perkiraan sebulan tidak dapat menentu besaran uang yang didapatnya, semua tergantung dari penghasilan ladang dan hasil dari panggilan kerja buruh (Manjing) dari orang lain, dimana perkiraan beliau per hari mendapatkan Rp.50.000. Tetapi jika pada bulan Ramadhan datang, mbah Katini mempunyai penghasilan lebih dari pesanan masyarakat desa untuk membuat kerupuk mantenan. Kerupuk mantenan adalah salah satu jajanan khas setiap rumah pada bulan ramadhan, dimana hanya mbah Katini yang bisa membuat jajanan tersebut di desa Demuk. Sehingga dengan adanya pemasukan dari semuanya itu mbah Katini dapat memenuhi kebutuhan ekonomi keluarga atau rumah tangga walaupun secara keseluruhan hanya cukup untuk makan, berobat dan membayar kebutuhan yang lain.

\section{KESIMPULAN}

$\mathrm{D}$ alam keseharian, perempuan memiliki peranan penting yang sangat luar biasa. Perempuan sangat dibutuhkan hampir di setiap aspek kehidupan, yaitu di dalam keluarga menjadi seorang ibu dan istri sedangkan diluar itu perempuan mampu bekerja dalam segala hal baik kehidupan bermasyarakat. Perempuan selagi bekerja di peran domestik dapat juga bekerja di publik, sedangkan laki-laki hanya dapat bekerja di publik tetapi belum tentu dapat bekerja domestik, para laki-laki membutuhkan perempuan dalam segala hal kehidupannya. Sehingga perempuan dapat mempunyai peran ganda dalam hidupnya, apalagi perempuan yang mempunyai status janda, dimana masyarakat Indonesia masih memandang sebelah mata dengan mereka. Padahal perempuan ini dapat mandiri dalam hal ekonomi dan menjadi tulang punggung keluarga. Sama halnya dengan perempuan lansia, dimasa tuanya sebenarnya mereka bisa hidup santai dan tidak perlu bekerja keras, tetapi kenyataan hidup masih ada perempuan lansia bekerja, survive dan menjadi tulang punggung keluarga untuk menghidupi keluarga atau rumah tangga dan dirinya sendiri.

Hasil penelitian menjelaskan bahwa baik laki-laki maupun perempuan yang masih produktif maupun sudah lanjut usia masih memiliki hak untuk bekerja dalam menghidupi kehidupan mereka. Karena kehidupan masyarakat apalagi di pedesaan, khususnya perempuan Jawa yang memiliki sistem kekeluargaan patriarki tidak bisa dianggap mudah dan fleksibel. Walaupun kehidupan mereka yang masih mayoritas masyarakat agraris, mereka masih bisa menyeimbangkan dengan baik antara segala kegiatan dan aktivitas menjadi suatu kebiasaan serta simbol atau tanda silaturahmi bagi masyarakat di desa.

Penelitian ini memperkuat bahwa, adanya pekerjaan dan kegiatan bagi para perempuan lansia sangat mempunyai nilai positif dalam kehidupan mereka. Perempuan lanjut Usia tidak harus tergantung kepada orang lain, tidak perlu merasakan meminjam uang kepada orang lain hanya untuk memenuhi kebutuhan hidup seharihari. Perempuan lansia yang memiliki pekerjaan dapat hidup mandiri, walaupun kemandirian ekonomi mereka tidak dapat dilihat secara keseluruhan tetapi bermanfaat bagi mereka yang memiliki kondisi lemah dan usia yang sudah tidak produktif lagi.

Kajian dan pembahasan dari hasil penelitian, maka pemerintah harus lebih peduli terhadap para lansia yang ada di pedesaan bukan hanya dari segi ekonomi tetapi dalam segala hal kesehatan, budaya, sosial dan lainnya. Sehingga mereka para lansia khususnya yang menjadi tulang punggung keluarga atau rumah tangga memiliki peluang pekerjaan yang lebih layak dan mendapatkan kehidupan ekonomi yang lebih bagus lagi dari sebelumnya. Khususnya bagi perempuan janda yang memiliki pandangan stereotipe di lingkungan masyarakat desa yang masih kental dengan adat istiadat atau budaya yang mereka miliki.

\section{E. UCAPAN TERIMAKASIH}

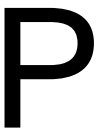
eneliti mengucapkan terima kasih kepada kedua orang tua peneliti yang memberikan dana dalam penelitian ini serta perangkat desa Demuk dan pendamping desa PKH yang sudah banyak membantu selama penelitian. 


\section{DAFTAR PUSTAKA}

Fadilah, R. (2015). Menuju Lansia Bahagia dan Tetap Produktif. Program Suara Pene Himpunan Psikologi Indonesia (HIMPSI) Mendukung Hari lansia Nasional dengan Tema "Peduli dan Mendukung Pemberdayaan Tiga Generasi".

Harianto, R. (2017, Agustus 23). Retrieved from Tantangan Bonus Demografi Bagi Indonesia: http://video.metrotvnews.com/primetime-news

Jannah, M. (2016). Resiliensi Lansia Perempuan Dalam Menyingkapi Permasalahan Hidup di Kota Yogyakarta. Thesis. Pascasarjana UIN Sunan Kalijaga Yogyakarta. Magister Ilmu Sains. Interdisciplinary Islamic Studies. Konsentrasi Pekerjaan Sosial.

Karang, A. M. (2018., 10. 8.). Bonus Demografi Indonesia Berakhir di 2036, Jumlah Lansia Bakal Naik. Retrieved 11. 26., 2018., from Kompas.com : https://regional.kompas.com/read/2018/10/08/05440801/bonus-demografi-Indonesia-berakhirdi-2036-jumlah-lansia-bakal-naik

Lestari, D. (2017). Aktivitas Ekonomi Usia Lanjut di Objek Wisata Pantai Depok. Pendidikan Sosiologi. Fakultas IImu Sosial. Universitas Negeri Yogyakarta.

Lestari, M., Natalya, N. P., Santosa, R. D., Puspitasari, N. P., \& Perry, O. A. (2016). Makna Kemandirian Pada Pekerja Lansia Perempuan Bali. Konferensi: Persilangan Identitas, Agensi dan Politik (20 Tahun Jurnal Perempuan) (pp. 310-330). Jakarta: Ariom Swiss-Belhotel Kemang.

Padmiati, E., \& Diyanayati, K. (2015). Pelayanan Sosial Lanjut Usia Dalam Keluarga. Balai Besar Penelitian dan Pengembangan Pelayanan Kesejahteraan Sosial (B2P3KS), 329-342.

Permanadeli, R. (2015). Dadi Wong Wadon: Representasi Sosial Perempuan Jawa di Era Modern. Yogyakarta: Pustaka Ifada.

Priyoto. (2015). INC Dalam Keperawatan Gerontik. Jakarta: Salemba Medika.

Pudjianto, R. (2017). Perempuan Jawa, Representasi dan Modernitas. Indonesia Journal Of Sociology and Education Policy, 125-132.

Sakina, A., \& Siti A., D. (2017). Menyoroti Budaya Patriarki di Indonesia. SOCIAL WORK JURNAL, $71-78$.

Sari, E. (2016). Faktor-Faktor yang Mempengaruhi Motivasi Kerja Pada Lansia. Skripsi. Program Studi Psikologi. Universitas Muhammadiyah Surakarta.

Spradley, J. (2006). Metode Etnografi. Edisi Kedua. Pengantar: DR. Amri Marzali, MA. Yogyakarta: Tiara Wacana.

Suartha, N. (2015). Kontribusi Ibu Rumah Tangga Dalam Meningkatkan Kesejahteraan Keluarga. Sebuah Studi Kasus di Kabupaten Badung Provinsi Bali. Jakarta: PT. Raja Garsindo Persada.

Sulistyastuti, D. R. (2017). Tantangan Indonesia Untuk Mengoptimalisasikan Bonus. JURNAL STUDI PEMUDA, 538-547. 